\title{
SHORT-TAILED SHREW PARTURITION DATE
}

\author{
ROBERT P. BERGER, 807 Coventry Road, Winnipeg, MB R3R 1B6
}

Short-tailed Shrews, l've discovered, are fairly plentiful in my neighbourhood near the Assiniboine River in southwestern Winnipeg, as Bob and Ruth Nero, who live down the street from me, have pointed out. ${ }^{3,4}$ Our tightly-fenced and treed 0.1 ha ( $1 / 4$ acre) backyard is occupied mainly by natural Trembling Aspen and Bur Oak. In 1996, between May and October, one of our two cats caught 24 shrews entirely within this confined space; at least this was the number brought to the house. My cat may have refrained from eating the shrews because of their strong scent glands.

In March 1999, I discovered a shrew in our garage, and a hole in a bag of birdseed stored there. Criddle pointed out that shrews in winter, including the Short-tailed Shrew, readily switch from preying on invertebrates and mice to eating seeds of various kinds. ${ }^{1}$ It has become apparent, however, that Shorttailed Shrews can be attracted to bird seed even in summer. ${ }^{3,4}$ I knew that Nero was keeping some captive shrews, used in winter as lures to trap Great Gray Owls for banding, so when I trapped my garage shrew alive on April 2, I presented it to him (despite protestations from my partner, Janis). I asked Nero if it was a male or a female, and he informed me, as he installed it in a small cage with suitable food and water, that you can't tell them apart externally. On the morning of April 5, however, it was clear that it was a female, for it had given birth overnight to seven apparently healthy young. Nero and I were surprised, for the shrew hadn't seemed especially large. Within 24 hours, however, it was obvious that the shrew had little or no interest in her offspring, perhaps owing to the trauma of being removed from her territory and placed in unfamiliar surroundings. All seven young were dead by the next day. Nero kept the mother shrew captive for 2 months, but its health gradually declined until on June 17 he euthanized her.

Actual birth dates for shrews are seldom observed, hence this incident provides a specific date for this region. The April 5 date fits the period of parturition that has been reported for this species, as does the number of young. Peterson, for example, states that "Breeding activity reaches its first peak about late March or early April..." Wrigley reports that this shrew has "an average of 5 (range of 3 to 10) young" with the first births appearing in April. ${ }^{6}$

I was also intrigued by another aspect of shrew behaviour. A shrew, when confronted by one of our three dogs in our yard, emitted a high-pitched vocalization, literally a scream, and possibly a defiant threat call. Nero told me he'd never heard anything like it, but he provided the following reference. Jackson, who intensively studied Short-tailed Shrews in captivity and in the wild, notes that when two shrews meet "they emit shrill cries or shrieks in angry protest. If the unwelcome contact continues the animal will utter sharp, shrill chatterings. This chattering usually starts with a high-pitched squeal and continues and ends with a rapid succession of short notes like zee-zee-zee-zee-zee-zee-zee-...." 2

\section{Acknowledgements}

I am grateful to Bob Nero for his assistance, and to Jim Duncan for word processing.

1. CRIDDLE, S. 1973. The granivorous habits of shrews. Can. Field-Nat. 87:69-70.

2. JACKSON, H.H.T. 1961. Mammals of Wisconsin. Univ. Wis. Press, Madison. 504pp. 
3. NERO, R.W. 1994. Short-tailed Shrew apparent cause of mortality of Eastern Screech-Owl. Blue Jay 52:176-178.

4. NERO, R.W., and R.F. NERO. 1999. A Short-tailed Shrew - Common Grackle encounter. Blue Jay 57: 122.
5. PETERSON, R.L. 1966. The mammals of eastern Canada. Oxford Univ. Press, Toronto. 465pp.

6. WRIGLEY, R.E. 1986. Mammals in North America. Hyperion Press, Winnipeg. 357pp.

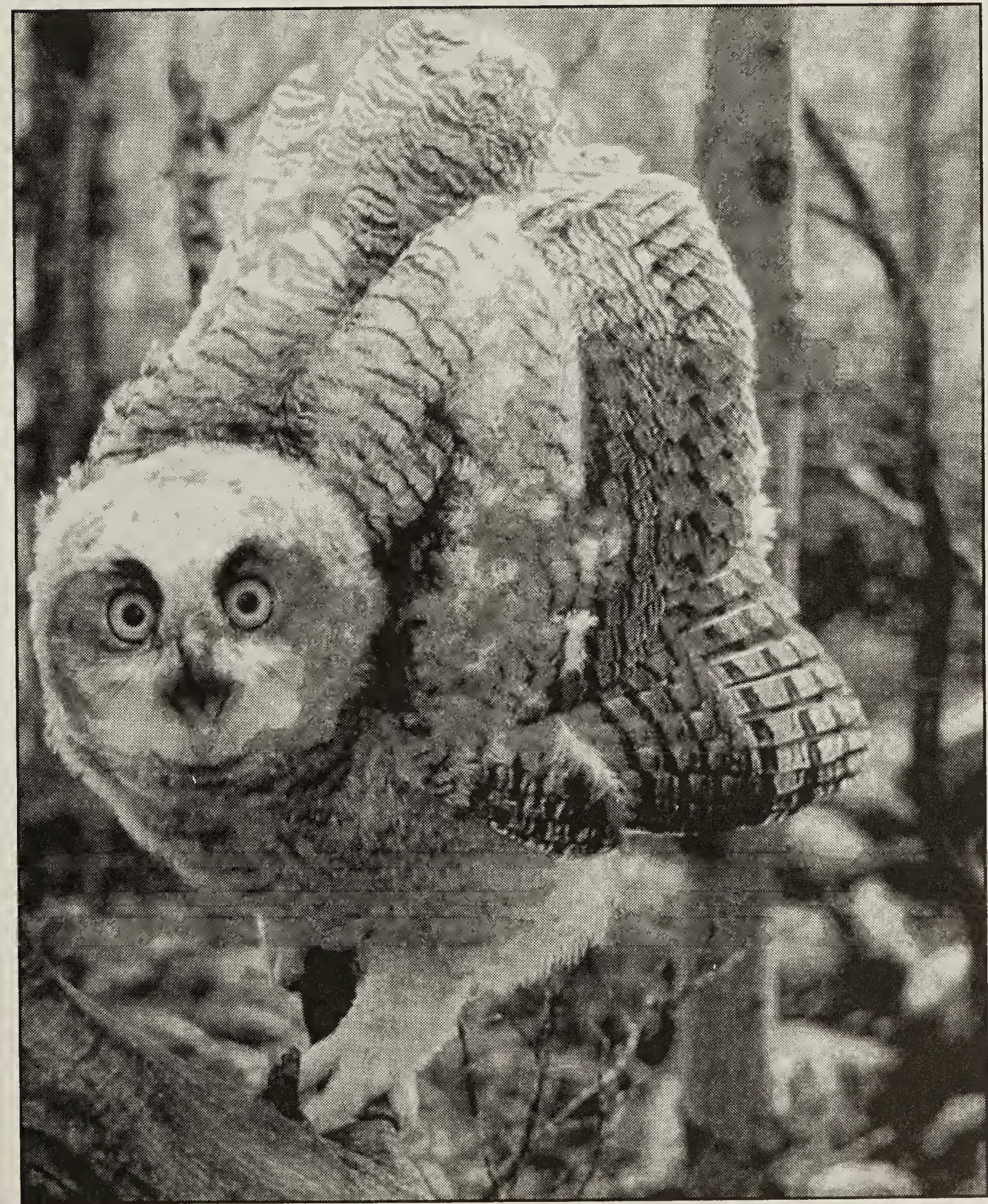

